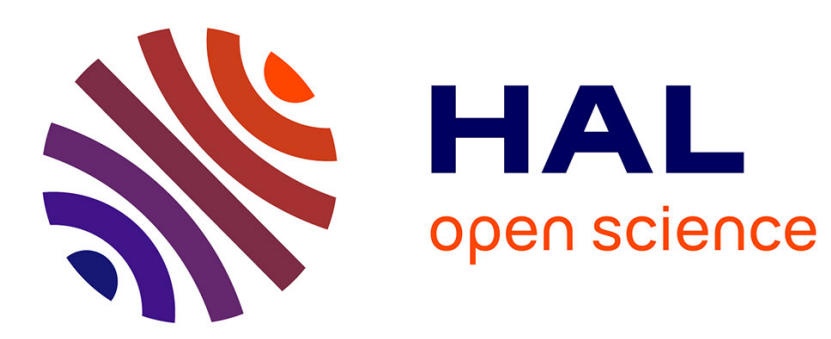

\title{
Anopheles of Bolivia: new records with an updated and annotated checklist
}

Frédéric Lardeux, Tamara Chavez, Roberto Rodriguez, Libia Torrez

\section{To cite this version:}

Frédéric Lardeux, Tamara Chavez, Roberto Rodriguez, Libia Torrez. Anopheles of Bolivia: new records with an updated and annotated checklist. Comptes Rendus Biologies, 2009, 332 (5), pp.489499. 10.1016/j.crvi.2008.11.001 . ird-01257049

\section{HAL Id: ird-01257049 \\ https://hal.ird.fr/ird-01257049}

Submitted on 15 Jan 2016

HAL is a multi-disciplinary open access archive for the deposit and dissemination of scientific research documents, whether they are published or not. The documents may come from teaching and research institutions in France or abroad, or from public or private research centers.
L'archive ouverte pluridisciplinaire HAL, est destinée au dépôt et à la diffusion de documents scientifiques de niveau recherche, publiés ou non, émanant des établissements d'enseignement et de recherche français ou étrangers, des laboratoires publics ou privés. 


\title{
Anopheles of Bolivia: new records with an updated and annotated checklist
}

\author{
Frédéric Lardeux ${ }^{\mathrm{a}, \mathrm{b}, \mathrm{c}, *}$, Tamara Chávez $^{\mathrm{c}}$, Roberto Rodríguez ${ }^{\mathrm{d}}$, Libia Torrez $^{\mathrm{c}}$ \\ a Institut de recherche pour le développement (IRD), C.P. 9214, La Paz, Bolivia \\ ${ }^{\mathrm{b}}$ Institut de recherche pour le développement (IRD), BP 64501, 34394 Montpellier cedex 5, France \\ ${ }^{\mathrm{c}}$ Instituto Nacional de Laboratorios de Salud (INLASA), Laboratorio de Entomología Medica, \\ Rafael Zubieta $n^{\circ}$ 1889, Miraflores, Casilla M-10019, La Paz, Bolivia \\ d Escuela Técnica de Salud Boliviano-Japonés de Cooperación Andina, Laboratorio de Entomología Medica, \\ Avenida Aniceto Arce 440, Cochabamba, Bolivia
}

Received 21 March 2008; accepted after revision 3 November 2008

Presented by Pierre Buser

\begin{abstract}
Anopheles squamifemur has been identified from CDC light trap collections carried out at Arca de Israel, a small community located in the extreme north-east of Bolivia (Pando Department) on the banks of the river Madera, on the border with Brazil. Anopheles costai and An. forattinii have been identified in place of An. mediopunctatus which has been removed from the Bolivian list of Anopheles species. The first identification of An. trinkae in Bolivia by Dr. J.C. Lien in 1984 is cleared. The presence of An. deaneorum in Bolivia has been confirmed by our mosquito captures carried out in Guayaramerín (Pando Department, north-east of Bolivia), a border city separated from the type locality of An. deaneorum, the Brasilian city of Guajara-Mirin, by the large Mamoré River. These new findings increase to 43 the total number of known Anopheles species for Bolivia for which an updated

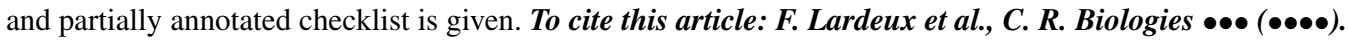

(C) 2008 Académie des sciences. Published by Elsevier Masson SAS. All rights reserved.
\end{abstract}

\section{Résumé}

Anopheles de Bolivie : Nouveaux signalements avec une liste d'espèces actualisée et commentée. Anopheles squamifemur a été identifié à partir de collectes faites avec des pièges lumineux de type CDC à Arca de Israel, une petite communauté située à l'extrême nord-est de la Bolivie (Département de Pando) sur les rives du fleuve Madera, à la frontière avec le Brésil. Anopheles costai et An. forattinii ont été identifiés en lieu et place d'An. mediopunctatus qui est supprimé de la liste des Anopheles de Bolivie. La première identification d'An. trinkae en Bolivie par le Dr. J.C. Lien en 1984 est précisée. La présence d'An. deaneorum en Bolivie a été confirmée par nos captures effectuées à Guayaramerín (Département de Pando, nord-est de la Bolivie), une ville frontière séparée de la localité type d'An. deaneorum (la ville brésilienne de Guajara-Mirin) par le grand fleuve Mamoré. Ces nouveaux résultats augmentent à 43 le nombre des espèces d'Anophèles connus de Bolivie, pour laquelle une liste actualisée et partiellement commentée est donnée. Pour citer cet article : F. Lardeux et al., C. R. Biologies $\bullet \bullet \bullet(\bullet \bullet \bullet \bullet)$.

(C) 2008 Académie des sciences. Published by Elsevier Masson SAS. All rights reserved.

\footnotetext{
* Corresponding author at: Institut de recherche pour le développement (IRD), BP 64501, 34394 Montpellier cedex 5, France.

E-mail address: lardeux@ird.fr (F. Lardeux).
} 


\section{Introduction}

Mosquito species that transmit Plasmodium parasites to humans belong to the genus Anopheles. In 2004, the genus Anopheles comprised six subgenera totaling 484 species: Anopheles (189 species), Cellia (239 species), Kerteszia (12 species), Lophopodomyia (6 species), Nyssorhynchus (33 species) and Stethomyia (239 species) [1]. Only Cellia is absent from South America where a provisional total of 85 Anopheles species were identified [2]. Taxonomical reorganizations are frequent, especially in Neotropical Anopheles. For example, in the Nysshorhynchus subgenus, intraspecific variations of morphological traits (that often exceed differences between species) have provoked indepth taxonomical research, the constant discovery of new species and frequent modifications in the Anopheles classification [3]. These reorganizations are also the consequences of new molecular approaches to taxonomy that have led to the discovery of new species, mainly sibling or cryptic ones. As such, checklists are always provisional and evolve with time.

At a country level, a significant step toward the understanding of malaria transmission is to be acquainted with a catalog of local Anopheles species and the correct identification of vector species among the list. This local catalog may evolve with time as it is generally prepared gradually by sampling surveys, accumulated knowledge on the local mosquito fauna and the evolution of taxonomical tools.

Bolivia is characterized by the varying nature of its biogeographical units and a high level of species diversity [4,5]. Not surprisingly, the number of mosquito species recognized there so far is high $(\approx 150)$ [2] and it is likely that new species (even for Science) will be discovered in this still poorly prospected country. Despite some founding works $[4,6]$, the mosquito fauna of Bolivia remains partially unknown. In the present study, a new record of Anopheles squamifemur from Bolivia is reported; An. costai and An. forattinii are identified in place of An. mediopunctatus; the discovery of An. trinkae in 1981 is commented and the presence of $A n$. deaneorum in Bolivia is specified. These new findings increase to 43 the total number of known Anopheles species for Bolivia for which an updated and partially annotated checklist is given.

\section{New records: discovery and comments}

\subsection{Anopheles (Lophopodomyia) squamifemur Antunes, 1937}

Three An. squamifemur specimens were collected on the $5^{\text {th }}$ of September 2005 at Arca de Israel (Pando Department, Federico Roman Province, Municipality of Nuevo Manoa (Nueva Esperanza)) a small community located in the extreme north-east of Bolivia, on the banks of the river Madera, on the border with Brazil (Fig. 1). This small settlement was founded in the year 2000 , but is at present the most populated of the area $(\approx 250-300$ inhabitants grouped in $\approx 70$ houses $)$. The area is characteristic of the humid Amazonian forest (thermicity index $710-740^{\circ} \mathrm{C}$, ombrothermic index 4.5-6.5 mm ${ }^{\circ} \mathrm{C}^{-1}$ and dry season ombrothermic index $0.5-2.3 \mathrm{~mm}^{\circ} \mathrm{C}^{-1}$ ), at a mean elevation of $\approx 120 \mathrm{~m} \mathrm{[5].}$ Two CDC light-traps were placed inside and outside a house $\left(\mathrm{S}_{10} 0^{\circ} 15^{\prime} 40^{\prime \prime} \mathrm{S}, 65^{\circ} 19^{\prime} 11^{\prime \prime} \mathrm{W}\right.$, altitude $\left.117 \mathrm{~m}\right)$ located outside of the community center, on the road to Nueva Esperanza, between 18:00 $\mathrm{h}$ and 6:00 h next morning. The site was surrounded by the Amazonian forest. One An. squamifemur female was captured inside the house along with two An. oswaldoi, while outside, two An. squamifemur females were collected along with four An. darlingi, four An. oswaldoi and one An. triannulatus. The presence of the characteristic tuff of long, erect black scales on the distal third of hind femurs permitted the unambiguous classification of the specimens as An. squamifemur.

The monotypic Subgenus Lophopodomyia was established in 1937 by Antunes with An. squamifemur as the type species [7]. At present, along with An. squamifemur, five other species belong to this strictly Neotropical Subgenus [1]: An. gilesi (Peryassú 1908); An. gomezdelatorrei Levi-Castillo, 1955; An. oiketorakras Osorno-Mesa, 1947; An. pseudotibiamaculatus Galvão and Barreto, 1941; and An. vargasi Gabaldón, CovaGarcía and López, 1941. From the Lophopodomyia Subgenus, only An. gilesi has been previously recorded from Bolivia [8,9] (Table 1).

Adults of the six species of this Subgenus are morphologically very close to those of the Anopheles Subgenus and are generally best distinguished by examining the male genitalia [10,11], except for An. squamifemur for which a special distinguishing mark exists: 
Table 1

Checklist of the Anopheles ${ }^{(1)}$ and their presence in Departments of Bolivia.

\begin{tabular}{|c|c|c|c|c|c|c|c|c|c|c|c|}
\hline Subgenus & & Species & Beni & Chuquisaca & Cochabamba & $\mathrm{La} \mathrm{Paz}$ & Oruro & Pando & Potosi & Santa Cruz & Tarija \\
\hline \multirow[t]{14}{*}{ Anopheles } & (2) & apicimacula Dyar \& Knab, 1906 & $\mathrm{X}$ & & & & & & & $\mathrm{X}$ & \\
\hline & * & costai Fonseca \& Ramos, 1939 & $\mathrm{X}$ & & $\mathrm{X}$ & & & $\mathrm{X}$ & & $\mathrm{X}$ & $\mathrm{X}$ \\
\hline & & eiseni Coquillett, 1902 & $\mathrm{X}$ & & & $\mathrm{X}$ & & & & & \\
\hline & * & fluminensis Root, 1927 & & & $\mathrm{X}$ & & & & & $\mathrm{X}$ & \\
\hline & * & forattinii Wilkerson \& Sallum, 1999 & $\mathrm{X}$ & & $\mathrm{X}$ & & & $\mathrm{X}$ & & $\mathrm{X}$ & $\mathrm{X}$ \\
\hline & & intermedius (Peryassú, 1908) & & & & & & & & $\mathrm{X}$ & \\
\hline & & maculipes (Theobald, 1903) & $\mathrm{X}$ & & & & & & & $\mathrm{X}$ & \\
\hline & $*$ & mattogrossensis Lutz \& Neiva, 1911 & $\mathrm{X}$ & & $\mathrm{X}$ & & & $\mathrm{X}$ & & $\mathrm{X}$ & $\mathrm{X}$ \\
\hline & & neomaculipalpus Curry, 1931 & & & & $\mathrm{X}$ & & & & $\mathrm{X}$ & \\
\hline & * & peryassui Dyar and Knab, 1908 & $\mathrm{X}$ & & & & & $\mathrm{X}$ & & & \\
\hline & * & pseudopunctipennis Theobald, 1901 & $?$ & $\mathrm{X}$ & $\mathrm{X}$ & $\mathrm{X}$ & & & $\mathrm{X}$ & $\mathrm{X}$ & $\mathrm{X}$ \\
\hline & & punctimacula Dyar and Knab, 1906 & & & & & & & & $X$ & \\
\hline & $*$ & shannoni Davis, 1931 & $X$ & & & & & $X$ & & & \\
\hline & & tibiamaculatus (Neiva, 1906) & & & & $\mathrm{X}$ & & & & & \\
\hline \multirow[t]{7}{*}{ Kerteszia } & & bambusicolus Komp, 1937 & & & & & & & & $X$ & \\
\hline & * & boliviensis (Theobald, 1905) & & & $X$ & $X$ & & & & & \\
\hline & & cruzii Dyar \& Knab, 1908 & & & $\mathrm{X}$ & $\mathrm{X}$ & & & & & \\
\hline & * & homunculus Komp, 1937 & & & $\mathrm{X}$ & $\mathrm{X}$ & & & & & \\
\hline & * & laneanus Corrêa \& Cerqueira, 1944 & & & $\mathrm{X}$ & $\mathrm{X}$ & & $\mathrm{X}$ & & $\mathrm{X}$ & \\
\hline & $*$ & lepidotus Zavortink, 1973 & & & $\mathrm{X}$ & & & & & & \\
\hline & & neivai Howard, Dyar \& Knab, 1913 & & & & $\mathrm{X}$ & & & & & \\
\hline \multirow[t]{2}{*}{ Lophopodomyia } & & gilesi (Peryassú, 1908) & & & $\mathrm{X}$ & $\mathrm{X}$ & & & & & \\
\hline & * & squamifemur Antunes, 1937 & & & & & & $X$ & & & \\
\hline \multirow[t]{19}{*}{ Nyssorhynchus } & (3)* & albitarsis s;s; Lynch Arribálzaga, 1878 & $\mathrm{X}$ & $\mathrm{X}$ & $\mathrm{X}$ & $\mathrm{X}$ & & $\mathrm{X}$ & & $\mathrm{X}$ & $\mathrm{X}$ \\
\hline & * & argyritarsis Robineau-Desvoidy, 1827 & $\mathrm{X}$ & $\mathrm{X}$ & $\mathrm{X}$ & $\mathrm{X}$ & & & & $\mathrm{X}$ & $\mathrm{X}$ \\
\hline & * & $\begin{array}{l}\text { benarrochi Gabaldón, } \\
\text { Cova-García \& López, } 1941\end{array}$ & & & $\mathrm{X}$ & $\mathrm{X}$ & & $\mathrm{X}$ & & & $\mathrm{X}$ \\
\hline & $*$ & braziliensis (Chagas, 1907) & $\mathrm{X}$ & $\mathrm{X}$ & $\mathrm{X}$ & & $\mathrm{X}$ & $\mathrm{X}$ & & $\mathrm{X}$ & \\
\hline & $*$ & darlingi Root, 1926 & $\mathrm{X}$ & & & & & $\mathrm{X}$ & & $\mathrm{X}$ & $?$ \\
\hline & * & deaneorum Rosa-Freitas, 1989 & $\mathrm{X}$ & & & & & $\mathrm{X}$ & & & \\
\hline & $*$ & evansae (Brethes, 1926) & $\mathrm{X}$ & & $\mathrm{X}$ & & & $\mathrm{X}$ & & $\mathrm{X}$ & $\mathrm{X}$ \\
\hline & & konderi Galvão \& Damasceno, 1942 & $\mathrm{X}$ & & & & & $\mathrm{X}$ & & & \\
\hline & & lutzii Cruz, 1901 & & & $\mathrm{X}$ & & & & & & \\
\hline & * & marajoara Galvão \& Damasceno, 1942 & & & $\mathrm{X}$ & & & & & & \\
\hline & $*$ & nuneztovari Gabaldón, 1940 & $\mathrm{X}$ & & $\mathrm{X}$ & $\mathrm{X}$ & & $\mathrm{X}$ & & $\mathrm{X}$ & $\mathrm{X}$ \\
\hline & $*$ & oswaldoi (Peryassú, 1922) & $\mathrm{X}$ & & $\mathrm{X}$ & $\mathrm{X}$ & & $\mathrm{X}$ & & $\mathrm{X}$ & \\
\hline & (4) & species "C" (oswaldoi complex) & & & $\mathrm{X}$ & & & & & & \\
\hline & * & parvus (Chagas, 1907) & & & & $\mathrm{X}$ & & & & & \\
\hline & * & $\begin{array}{l}\text { rangeli Gabaldón, Cova-García } \\
\text { \& López, } 1940\end{array}$ & $\mathrm{X}$ & & $\mathrm{X}$ & $\mathrm{X}$ & & $\mathrm{X}$ & & $\mathrm{X}$ & $\mathrm{X}$ \\
\hline & * & rondoni (Neiva et Pinto, 1922) & $\mathrm{X}$ & & $\mathrm{X}$ & & & & & $\mathrm{X}$ & $\mathrm{X}$ \\
\hline & $*$ & strodei Root, 1926 & $\mathrm{X}$ & & $\mathrm{X}$ & & & $\mathrm{X}$ & & $\mathrm{X}$ & $\mathrm{X}$ \\
\hline & ${ }^{(5)} *$ & triannulatus (Neiva and Pinto, 1922) & $\mathrm{X}$ & & $\mathrm{X}$ & $\mathrm{X}$ & & $\mathrm{X}$ & & $\mathrm{X}$ & $\mathrm{X}$ \\
\hline & * & trinkae Faran, 1979 & $\mathrm{X}$ & & $\mathrm{X}$ & $\mathrm{X}$ & & $\mathrm{X}$ & & $\mathrm{X}$ & $\mathrm{X}$ \\
\hline Stethomyia & & nimbus (Theobald, 1902) & $X$ & & & & & & & & \\
\hline
\end{tabular}

* Species present at least in one of the Bolivian collections at INLASA or Escuela Técnica de Salud.

? Indicates that in the past the species has been mentioned in the Department (by [4] in particular) but that the present authors do not agree with that distribution. The species is not present anymore and therefore either it has disappeared from the region, either the species could have been misidentified at that time.

(1) An. (Nysshorhynchus) galvaoi, An.(N.) lanei and An. (Kerteszia) bellator have not been added to this list (see text).

(2) Doubtful presence; probably confused with intermedius.

(3) An. allopha Peryassú, 1921 (nomen dubium) as described by Faran \& Linthicum (1981) is also present.

(4) Identified by molecular tools (Brelsfoard et al., 2005), not yet described, close to oswaldoi.

(5) Various mutant forms exist in Bolivia, at least triannulatus davisi (see text). 
both sexes show a characteristic tuff of long, erect black scales on slightly less than distal third of hind femurs that permits an easy and undoubted identification. In the Neotropical region, An. squamifemur is the only Anopheles species exhibiting such scale tuffs on its hindlegs. Other Anopheles species are known to exhibit tuffs of scales on their legs such as all the species of the Lophoscelomyia Series (Subgenus Anopheles) from the Hindu-Asiatic region and the Malaysian species An. wellingtonianus Alcock, 1912 (Subgenus Anopheles, Series Anopheles).

The description of An. squamifemur female was first published by Antunes [7], then the male was described [12] and later the larva, pupa and egg [13]. All stages of An. squamifemur can easily be distinguished from the other species of the Lophopodomyia Subgenus [13]. However, using usual identification keys $[14,15]$, the $4^{\text {th }}$ stage larvae would be misidentified as An. (Anopheles) eiseni which is also present in Bolivia (Table 1). However, An. squamifemur larvae can be easily differentiated by the presence of a palmate tuft hair on the first abdominal segment (seta 1-I) and a generally shorter size as compared to eiseni [13].

An. squamifemur is also known from Brazil (States of Para and Amazonas, close to the Venezuelan border $[12,16]$ and State of Rondonia, frontier with Bolivia [17,18]), Colombia [7] from where comes the holotype, Costa Rica [19], French Guiana [20], Panama [21], Peru [22], Suriname [23] and Venezuela [24].

Lophopodomyia mosquitoes are sylvatic species, biting man and animals at twilight and their aquatic stages are passed in shaded side pools of streams rich in organic matter [25]. An. squamifemur follows these rules: it has always been captured in tropical humid forest areas [[18,20,21,26], among others]. It is, for example, widespread and locally common in the Atlantic coastal forests of the Isthmus of Panama [13]. Little is known of the bionomics of An. squamifemur. Immature stages have rarely been collected and the only types of breeding sites known at present are from Venezuela [27] and Peru [28]. They were encountered in small shaded areas in the banks of small or large rivers, where the stream is slow and permits the accumulation of natural floating debris and vegetation (Eichhornia crassiipes y Pistia stratiotes). Such an area may also be the consequence of a fallen tree trunk (for example) which enables the accumulation of organic debris and the slowing down of the stream. Few An. squamifemur were also collected in ponds [27]. Adults were also collected in Panama by horse-bait traps $[13,29]$ and light traps $[21,26]$, in a forest area of French Guiana [20] and at the borders of forests using animal baits at twilight [30]. An. squam- ifemur may bite humans [13], but nothing is known on its importance as a Plasmodium vector. It is probably limited, due to generally low densities of this mosquito in areas where human populations are also scarce.

In Bolivia, the surroundings of the collection site were similar to the few descriptions of other adult collecting sites elsewhere $[18,20,21,26,30]$. The Bolivian collecting site was situated in a characteristic Amazonian semi-evergreen seasonal forest (Fig. 1) and it is likely that An. squamifemur may extend its distribution range in Bolivia throughout the extension of this biogeographic region in that country.

\subsection{Anopheles (Anopheles) costai Fonseca \& Ramos, 1939 and An. (An.) forattinii Wilkerson \& Sallum, 1999}

These two species belong to the Anopheles subgenus (Series Arribálzagia) and are very closely related to An. mediopunctatus. An. costai has been recently resurrected from synonymy with An. mediopunctatus [31], while An. forattinii has been recently described [32]. These three species are morphologically similar and therefore were misidentified as An. mediopunctatus for several years in South America, as a consequence of identifications based only on adult female characters which could not discriminate [31]. An. costai and An. forattinii females are undistinguishable, and apparently undistinguishable from An. mediopunctatus except by the shape of the cercus [31,32]. Differences amongst the three species are more marked in male genitalia, pupae and larvae. In Bolivia, where the usual keys of Gorham et al. [9,15] or Stojanovich et al. [14] are routinely used to identify Anopheles species, An. costai and An. forattinii, absent from these keys, were de facto confused with An. mediopunctatus. The correct identification of these two species in Bolivia was recently carried out by mounting larvae collected during the "Bolivian Vectors Mapping Project" and using the differentiating characters from [31,32]. Both species were first identified in the Cochabamba Department, Chapare Province, $\mathrm{Mu}-$ nicipality of Villa Tunari: An. forattini from the Moleto locality and An. costai from the Villa 14 de septiembre locality (Fig. 1). However, only a few larvae from these two localities were classified undoubtedly as costai or forattinii. Other several tens of larvae examined from five other localities of the Chapare Region (Aroma, Moleto, San Mateo Bajo, San Rafael, Villa 14 de septiembre) and two localities from the Tarija Department in the south of Bolivia (Sachapera in the Municipality of Yacuiba (Gran Chaco Province), and Valle Dorado in the Municipality of Padcaya (Arce Province)) (Fig. 1) presented a mixture of characters that prohibited a clear 


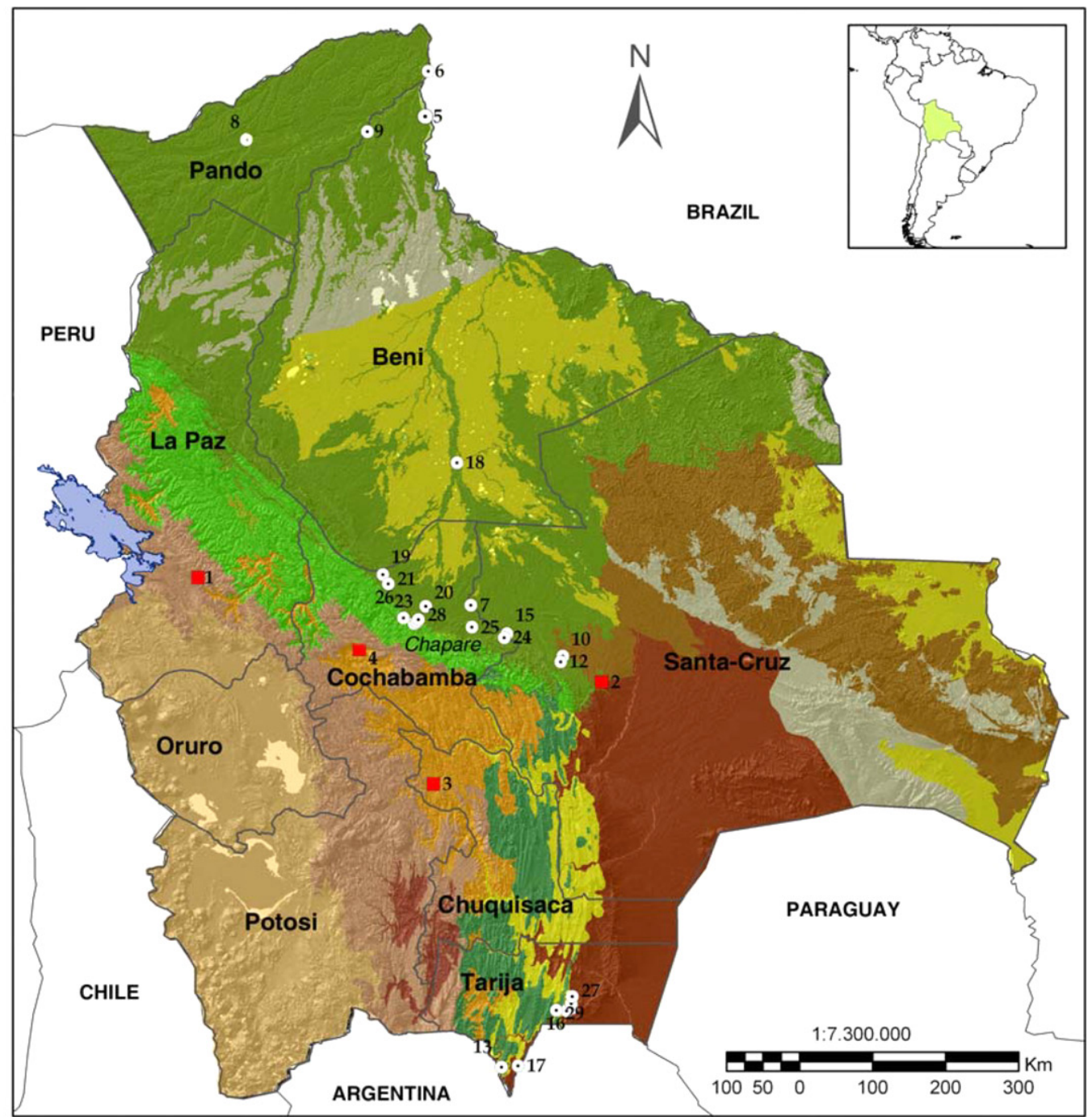

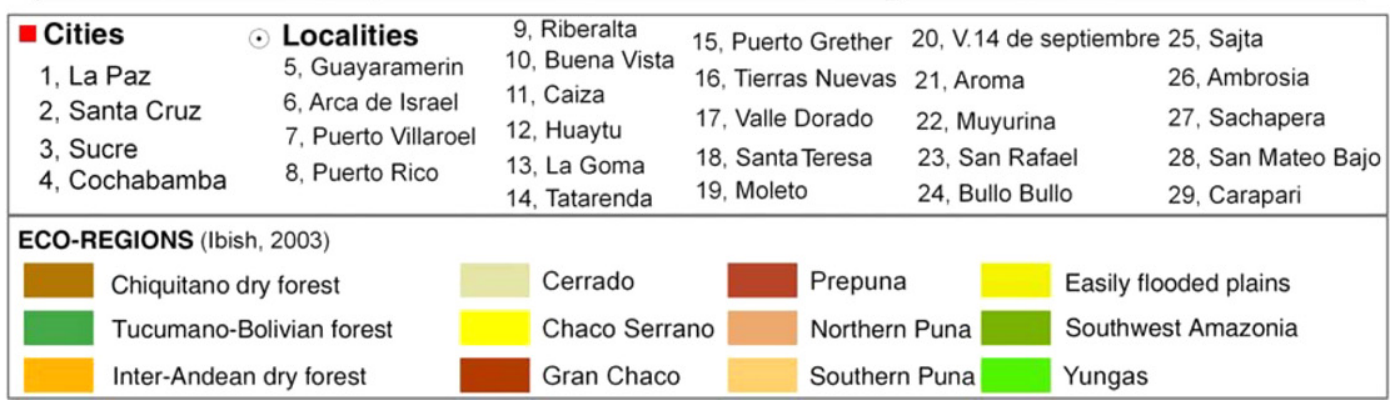

Fig. 1. The nine Departments of Bolivia, eco-regions [following [68]] and localities cited in the text.

classification. They shared characters of both species, even amongst the most discriminating ones (i.e., the antenna length/width, setae 3C, 4C, 9C, 12C, 14C, 7P, 13P, 2S and 1-II) [31]. To sum up the determination results, some larvae shared more characters with forattini (in particular in the south of Bolivia), while others more with costai. However, none were very close to mediopunctatus s.s. although sharing some of its characters (on setae 8P for example). If costai, forattini and mediopunctatus are really separated species and not mutant forms, some larvae from Bolivia may represent something else characterized by a mixture of 
(at least) the two former species. Genetic analysis (in prep.) of Bolivian specimens will likely give some cues to clear this situation. Larval sites were shaded pools ( $>40 \mathrm{~cm}$ deep and $<10 \mathrm{~m}^{2}$ ) in the margin of small rivers, in forest situations, at low altitude (200-300 m) with cold clear water (with or without floating debris and algae).

Adults An. mediopunctatus s.l. formerly identified from the Bolivian collections came from various sites of Bolivia, at low altitude: (1) in the Cochabamba Department, Chapare Province, localities of Muyurina, Ambrosia, San Mateo alto, San Mateo Bajo and Aroma; Carrasco Province, localities of Puerto Villaroel, Bulo Bulo and Sajta; (2) Santa Cruz Department, Ichilo Province, localities of Buena Vista and Huaytu, (3) Pando Department, Manuripi Province, locality of Puerto Rico; (4) Beni Department, Vaca Diez Province, localities of Riberalta and Guayaramerin, and (5) Tarija Department, Gran Chaco Province, localities of Carapari, Estacion Caiza and Sachapera; Arce Province, localities of La Goma and Valle Dorado (Fig. 1). These adults were examined using the discriminating character of the cercus (elliptical for An. costai and An. forattinii, and triangular for An. mediopunctatus) [31, 32]. Although it was impossible to classify them as An. costai or An. forattinii because of the exact morphological similarity of the two species for this character, they were not An. mediopunctatus s.s. It seems that An. mediopunctatus s.s. is at present only known from southeastern Brazil [32], and because none of the specimen examined from Bolivia was identified as $A n$. mediopunctatus s.s., this species was removed from the list of Bolivian Anopheles (Table 1). However, in Bolivia, more research is needed to clarify the taxonomic status of An. costai, An. forattini and the closely related forms encountered.

An. costai is also known from Argentina, Brazil, Colombia, French Guiana, Trinidad, Tobago, Panama, Peru, Surinam [31], and Venezuela [33] and might be present in all other countries where An. mediopunctatus was formerly (mis)identified: British Guiana, Colombia, Ecuador, Mexico [31]. An. forattinii is also known from Amazonian Brazil, Colombia, French Guiana, Peru, Surinam [32] and Venezuela [33].

Little is known about the biology of the two mentioned species, but in Bolivia their distribution range is wide, from the north (Amazonian region) to the south, but always in areas of low altitude $(<600 \mathrm{~m})$, in ecoregions such as Southwest Amazonia and in the lower parts of the Yungas and the Tucumano-Bolivian Forest (Fig. 1). An. mediopunctatus s.l. can be involved in malaria transmission [31]. However, in Bolivia, because of the rarity and low densities of An. costai and An. forattinii and the low human densities where these species have been found, their role as a malaria vector might be limited.

\subsection{Anopheles (Nysshorynchus) deaneorum Rosa-Freitas, 1989 and the albitarsis complex}

This species was captured during surveys we carried out in 2002-2003 in Guayaramerín, a city of $\approx 35000$ inhabitants on the banks of the Mamore River, a river $\approx 1 \mathrm{~km}$ wide, on the border with Brazil (Fig. 1). Guayaramerín is facing its "sister" Brazilian city (GuajaraMirin) of similar size, and from which An. deaneorum was first described and included in the albitarsis complex [34]. Adults An. deaneorum captured in Guayaramerín were distinguished from the closely related species An. albitarsis s.s. also present in the samples by a paler general external appearance for An. deaneorum, and the insertion of postlateral tufts of black scales appearing from the third tergite for An. albitarsis and from the fourth tergite for An. deaneorum [34]. The presence of An. deaneorum in Guayaramerín was also reported shortly before us in 2002 [35], but it has been impossible to examine specimens from these collections and therefore the presence of the species could not be confirmed at that time.

An. deaneorum is one of the five species of the albitarsis complex, along with albitarsis s.s., albitarsis sp. B, albitarsis sp. E and An. marajoara [36-38]. In Bolivia, it is likely that An. deaneorum has been confused for several years with An. albitarsis s.s. because of their very close morphological appearance. In other countries, species of the albitarsis complex are known to transmit Plasmodium sp., but further research is needed to ascertain the malaria vector status of each of these cryptic species and in particular the role of the three (An. deaneorum, An. albitarsis s.s. and An. marajoara) that have been identified in Bolivia (Table 1). In the past, An. albitarsis has also been divided in two closely related species: An. albitarsis and An. allopha [39]. Some specimens labelled An. allopha were found in the collection of pinned adults at Escuela Técnica de Salud Boliviano-Japonés de Cooperación Andina (Cochabamba). Although the two species might be morphologically distinguished [39], An. allopha is now in a nomen dubium [2,40]. However, Bolivian specimens matched the description of both "species" ( $A n$. allopha and An. albitarsis) as described by Faran and Linthicum [39]. 


\subsection{Anopheles (Nyssorhynchus) trinkae Faran, 1979}

The history of An. trinkae in Bolivia was made possible by the examination of apocrypha literature, mainly internal reports of Dr. Lien (a former collaborating scientist) to the Bolivian Ministry of Health from 1980 to 1985, and held in the Entomology Laboratory at Escuela Tecnica de Salud Boliviano-Japonés de Cooperación Andina (Cochabamba, Bolivia) [41]. An. trinkae has been described in 1979 and its presence in Bolivia was at that time hypothesized [42]. Its real identification in Bolivia was confirmed by Lien in 1981 [43]. Unfortunately this discovery went unnoticed because of the unavailability of the local Bolivian journal where it was published. Lien, who at that time worked in Bolivia with one of us (RR), first identified An. trinkae from San Mateo Bajo (S 17.0165, W 65.4378, Altitude $351 \mathrm{~m}$ ), a small community in the Chapare Province of the Cochabamba Department, by a careful examination of larvae and adults reared in the laboratory.

An. trinkae belongs to the Albimanus Section of the Nyssorhynchus Blanchard Subgenus of Anopheles. In this Section, it is classified in the Oswaldoi Subgroup of the Oswaldoi Group of the Oswaldoi Series [44]. The Subgroup comprises eleven species [1] of which two: An. rangeli Gabaldón, Cova García and López, 1940 and An. nuneztovari Gabaldón, 1940 (or more precisely the nuneztovari complex) are morphologically very close to An. trinkae. As such, the adult females of An. trinkae, An. nuneztovari and An. rangeli can sometimes be confused due to intraspecific variability and the paucity of reliable differentiating characters [39]. As a consequence, before 1979, An. trinkae was misidentified as An. nuneztovari or An. rangeli. In Bolivia, where the three species are present (Table 1), the latter misidentification was the rule. Since the identification of An. trinkae in Bolivia, its presence has been confirmed by molecular tools $[45,46]$. In Bolivia, it has a wide distribution range from the Andes (tropical areas) in the Departments of La Paz (Yungas region), Cochabamba (Chapare region), Santa-Cruz and Tarija, to the Amazonian region in the Departments of Pando and Beni (to a lesser extent) (Fig. 1). This species is also known to occur along the eastern slope of the Andes in Colombia [42], Ecuador [42] and Peru [47]. It is known as a poor malaria ( $P$. vivax) transmitter $[39,44,47]$. In Bolivia, it is suspected to be a malaria vector in some localities of the Chapare region of the Cochabamba Department, along with An. species C [48]. However, because of its feeding behavior (mostly zoophilic) and its low susceptibility to Plasmodium infection, its role as an efficient (and locally important) vector in Bolivia still remains to be clarified.

\section{Updated checklist of Anopheles of Bolivia and comments on some species}

The establishment of the checklist was based on (1) examination of collected material from the "Bolivian Vectors Mapping Project" carried out since 2005 at Instituto Nacional de Laboratorios de Salud (INLASA), La Paz (Laboratorio de Entomología Medica, curators $\mathrm{TC}$ and LT) and from previous collected material from collections at Escuela Técnica de Salud BolivianoJaponés de Cooperación Andina, Cochabamba (Laboratorio de Entomología Medica, curator RR), and (2) on previously published but incomplete lists $[[4,6,8-10,15$, 41,49-55], amongst the most significant].

The Anopheles checklist for Bolivia is given in Table 1 with a provisional distribution of the species within the nine Departments of Bolivia. The Department of Oruro lacks the presence of any Anopheles species because of the ecological conditions in this Altiplanic region ( $>3500 \mathrm{~m}$ altitude, mean annual temperature $11^{\circ} \mathrm{C}$ ). The Department of Potosi shares the same general ecological conditions but has some parts of its northern territory in the dry valley ecosystem of the Andes spur where only An. pseudopunctipennis can be found. Elsewhere, the Anopheles diversity is variable, but higher areas with a tropical or sub tropical climate, at altitudes 200-700 m: Amazonian region of Pando and Beni Department, Yungas region of La Paz Department, Chapare region of the Cochabamba Department, "Wet Chaco" of the Tarija Department, principally in the Carapari/Yacuiba area etc.). The five subgenera of South America are present in Bolivia. The subgenus Anopheles is represented by 14 species, and the subgenera Kerteszia, Lophopodomyia, Nysshorhynchus and Stethomyia by 7, 2, 19 and 1 species, respectively. A total of 43 Anopheles species are identified in Bolivia of which 28 are preserved in at least one of the current Bolivian collections kept at the above mentioned Institutions.

The presence in Bolivia of some of the listed species is still questionable. In Bolivia, An. apicimacula is probably confused with An. intermedius [15]. As a matter of fact, An. apicimacula is essentially a "northern" species of South America, with confirmed literature records from Colombia, Ecuador, Guyana, Mexico, Suriname, Trinidad and Tobago, Central America and Venezuela [2]. Likewise, An. punctimacula could be An. calderoni, described from Peru (Bolivia's neighbour country) [56] and where An. punctimacula was erroneously identified. 
It could also be An. malefactor, which was retrieved from synonymy with An. punctimacula [57]. Because we have not had access to Bolivian specimens of "An. punctimacula", either from Bolivian collections or from our captures, these doubts could not be removed. An. neivai is another species never captured again in Bolivia although mentioned (with an interrogation point) in the "Catalog of the Mosquitoes of the World" [4].

An. pseudopunctipennis is known to be a species complex comprised of at least three species [58], with numerous subspecies and varieties [2]. In Bolivia a larval form ("short tail") sympatric with the standard form is under study (Lardeux, unpublished data). This form can be distinguished by a very short black tail (in opposition to the long black tail of the standard description) in each posterior spiracular plate of L4 larvae. In the past, the species has also been mentioned in the Beni Department (Moxos y Vaca Diez Provinces) [4]. However, these Provinces are far from the known geographical distribution range of that species in Bolivia (mainly in the foothills of the Andes) and therefore, the presence of An. pseudopunctipennis in the two above mentioned Provinces of the Beni Department is doubtful and has never been confirmed since.

An. darlingi is also known to exhibit morphological variations [59] and in Bolivia, a form sympatric with the standard one has been discovered in Guayaramerín. It exhibits a lack of prehumeral and humeral pale costal spots on its wings as compared to a standard specimen and as such, the first third of the costa is entirely black. However, the "black" form could not be separated from the standard one by molecular analysis (Lardeux, in prep.). In the past, An. darlingi has been identified from the Gran Chaco Province of the Tarija Department (very few individuals in one single location) [4]. However, despite numerous efforts we were unable to recapture this species again in that region and there is a reasonable assumption that this species is nowadays absent from the Gran Chaco area. In Bolivia, its distribution area is clearly the Southwest Amazonia Eco-region in the north of the country, and in the west, areas border with Brazil.

Recently in the Cochabamba Department, an apparently new to Science species, very close to An. oswaldoi, has been identified by molecular analysis and provisionally named "species C" [55]. It is very common in the Chapare and Carrasco Provinces (in or near the foothill regions at $200-500 \mathrm{~m}$ above sea level close to the locality of Chimoré) and is suspected to be a vector of Plasmodium vivax in that region, because of its abundance and the absence of other possible vectors (except An. trinkae) [48]. This species has been added to the list, though its description has not yet been published.
An. (Nysshorhynchus) triannulatus is closely related to $A n$. rondoni, An. benarrochi and An. strodei also present in Bolivia (Table 1). It is known to be highly polymorphic, with numerous mutant forms [44] and even cryptic species $[60,61]$. However, two subspecies are generally recognized: An. triannulatus triannulatus and An. triannulatus davisi [62]. The principal characteristics used to distinguish $t$. triannulatus from $t$. $d a$ visi are: (1) larval hair 1-P filamentous and with more branches than in davisi, (2) females smaller than that of davisi, (3) adult wing with sectoral dark spot of $\mathrm{Cu}$ larger and reaching the furcation, and (4) IV hind tarsomer generally all black in $t$. triannulatus and white in its distal part in $t$. davisi. According to the key of Consoli and Lourenço-de-Oliveira [63], most Bolivian larvae from various geographical sites belong to the triannulatus davisi form (i.e., $4^{\text {th }}$ instar larva with seta 1-P leaflets lanceolate, and long lateral arms of the spiracular apparatus). However, variations exist and many specimens exhibit mixed characteristics of the various described forms. For example, larvae from the north of the country (Pando and Beni Departments) exhibit large lateral arms of the spiracular apparatus while in some (but not all) places in the south (for example, the locality of Tatarenda, [Tarija Department, Gran Chaco Province, Yuacuiba Municipality]), these arms are very small in comparison, and make one think of a partial description of the $t$. triannulatus form. Similarly, adults can be divided into two distinct groups by their overall size. For example, in the north of Bolivia (Localities of Guayaramerín, Puerto Rico, etc.) and in the Chapare region in the center, An. triannulatus is a very small species (somewhat similar to the $t$. triannulatus form) while in the south of the country, the size of the adults is much larger. Moreover, inside these groups, other differences arise, such as the color of the IV hind tarsomer whose pattern varies from one region to another (for example, the "black" tarsomer form is more abundant in the south of Bolivia and the white one in the north, although some localities may exhibit "black" and "white" forms in sympatry). Some variations have also been noticed in the sectoral dark spots of $\mathrm{Cu}$ reaching or not the furcation and in the dark spots of $\mathrm{Cu} 1$, but without any relationship with the color of the IV hind tarsomer. However, even if davisi is the predominant form, observed variations and mixed characters account for more complex relationships that do not match with previous descriptions. In Bolivia the clarification of the various forms is under study (small and large adults, $4^{\text {th }}$ instar larvae with long or very short lateral arms, "black" and "white" IV hind tarsomer etc. and specimens which exhibit mixed characters). The mix- 
ing of characters of both $t$. davisi and t. triannulatus has also been noticed in Brazil [10], which might support the hypothesis that triannulatus is one single but variable species [44]. Recently, An. halophylus has been described from Brazil [64]. It is a very closely related species which differ from An. triannulatus by some $4^{\text {th }}$ instar larvae characteristics (seta 1-P with very narrow and filiforme branches, and very small size of the lateral arms of the spiracular apparatus) and by the shape of the ventral lobe of the claspette of the male genitalia. In Bolivia, larvae and male genitalia examined from several localities indicated that An. halophylus is not present (Localities sampled, from north to south of the country: Puerto-Rico [Pando Department]; Guayaramerín and Santa Teresa [Beni Department]; Puerto Grether [Ichilo Province, Santa Cruz Department]; Caiza, Tatarenda and Tierras Nuevas [Gran Chaco province, Tarija Department]) (Fig. 1).

The albitarsis complex is represented in Bolivia by the three species albitarsis s.s., deaneorum and marajoara. As stated above, some Anopheles specimen found in the Cochabamba collection also matched the description given by Faran and Linthicum [39] for An. allopha. However, An. allopha has been declared to be a nomen dubium $[2,40]$ and since, its status has never been cleared [65]. Some recent works have dealt with the molecular identification of cryptic species in the albitarsis complex [38], and it would be interesting to process Bolivian "allopha" specimens with the published primers to clear their taxonomic status: do they belong to the albitarsis complex?, are they part of another cryptic species?, or are they a variety of argyritarsis as some authors seem to place "allopha" (see review in [65])? Because of the unclear taxonomic status of An. allopha, it was not maintained as a valid name in the Bolivian list of Anopheles.

Although three species have been cited for Bolivia in the past, they are not in the present list because (1) of the uniqueness of the sources that could not have been cross-verified and (2) we were unable to capture these species again in the field where they were reported or encounter them in one of the actual Bolivian collections. The first one is An. (Nysshorhynchus) galvaoi Causey, Deane \& Deane, 1943, which has been listed only by Lien in a provisional list of Bolivian Anopheles [41], but we unfortunately did not find it in his collection at Escuela Técnica de Salud Boliviano-Japonés de Cooperación Andina (Cochabamba). The second one is An. (Kerteszia) bellator Dyar et Knab, 1906, listed again by Lien but absent from his collection. Larvae may also have been collected in the Chapare region of the Cochabamba Department [66]. However, the species has never been captured again in the mentioned Chapare spots and, moreover, the larval sites described [63] did not match the standard larval site description for that species. It is thus likely that An. bellator has been misidentified. The third one is An. lanei, identified once by Lien [41]. However, An. lanei is probable an endemic species of Serra da Mantiqueira, state of São Paolo, Brazil [67] and therefore, its presence in Bolivia is very doubtful.

\section{Conclusion}

Bolivia is still a poorly prospected country for its entomofauna and it is likely that new species (even for Science) will be discovered there. New molecular tools will help in better understanding the Anopheles classification, and better identifying species which differ only in subtle morphological characteristics that are not always easy to track with the current taxonomical identification keys. The actual Anopheles checklist for Bolivia will evolve, gaining in diversity and also in precision with the work required to remove all the above-mentioned doubts.

\section{Acknowledgements}

The authors would like to thank especially J.L. Laura and Renata Salas from INLASA (La Paz), who participated in our field collecting trips but also helped a lot in the identification of species (especially An. costai and $A n$. forattinii) and in the study of the various forms of An. pseudopunctipennis, An. darlingi and An. triannulatus.

The authors would also like to thank all the personnel who participated in the field collecting trips planned within the "Bolivian Vectors Mapping Project" and particularly E. Quispe (INLASA) who placed the CDC light traps in which An. squamifemur was identified. The other participants to the project who, unluckily, did not collect An. squamifemur because they were not at the right place at the right moment, did in fact a great job both in the field while capturing mosquitoes as well as in the laboratory curing the collection: (alphabetical order in each participating Institution): INLASA: C. Aliaga, P. Durán, V. Quispe, R. López, R. Tejerina, Roberto Salas, E. Siñani, E. Zegarra; Escuela Técnica de Salud Boliviano-Japonés de Cooperación Andina: D. Ribera; Servicio Departamental de Salud Tarija (SEDES Tarija): M. Gallardo, B. Mollo, J. Vidaurre. A special thank to Dr. A. Matías (formerly entomologist at Health Ministry of Bolivia) who preserves in his collection the specimens of An. squamifemur collected by E. Quispe. 
The authors thank W. Tejeda (Universidad Mayor de San Andrès, La Paz) who draw the map of Bolivia in Fig. 1, and S. Featherston for correcting the English spelling.

\section{References}

[1] R.E. Harbach, The classification of genus Anopheles (Diptera: Culicidae): a working hypothesis of phylogenetic relationships, Bull. Entomol. Res. 94 (2004) 537-553.

[2] Walter Reed Biosystematics Unit, Systematic Catalog of the Culicidae - Bolivia. Available from: http://www. mosquitocatalog.org/countries/grid.asp, 2007.

[3] L.P. Lounibos, J.E. Conn, Malaria vector heterogeneity in South America, Amer. Entomol. 46 (2000) 238-249.

[4] A.F. Prosen, R.U. Carcavallo, A. Martinez, Culicidae de Bolivia, An. Inst. Med. Reg. 6 (1962) 59-124.

[5] G. Navarro, M. Maldonado, Geografía Ecológica de Bolivia. Vegetación y ambientes acuáticos, Fundación Simón I. Patino, Cochabamba, 2006.

[6] N.L. Cerqueira, Lista dos mosquitos da Bolivia, Mem. Inst. Oswaldo Cruz 39 (1943) 15-36.

[7] P.C.A. Antunes, A new Anopheles and a new Goeldia from Colombia (Dipt. Culic.), Bull. Entomol. Res. 28 (1937) 69-73.

[8] C. Moscoso-Carrasco, Bolivia Elimina su Malaria, M.S.P., La Paz, 1963.

[9] J.R. Gorham, C.J. Stojanovich, H.G. Scout, Clave ilustrada para los mosquitos anofelinos de Sudamérica oriental, U.S. Dep. Hlth. Educ. Welf., N.C.D.C., Atlanta, 1967.

[10] O.P. Forattini, Entomologia Medica, vol. I. Parte Geral, Díptera, Anophelini, Faculdade de Higiene e Saúde Pública, São Paolo, 1962.

[11] P. Cova García, E. Sutil, Clave para la identificación de los anofelinos de Venezuela por las terminalia del macho, Bol. Dir. Mal. Sanea. Amb. 15 (1976) 12-32.

[12] L.M. Deane, M.P. Deane, R.G. Damasceno, Encontro e descrição do macho do Anopheles (Lophopodomyia) squamifemur Antunes, 1937 (Diptera, Culicidae), Ver. Brasil. Biol. 9 (1949) $497-$ 504.

[13] M.M. Boreham, D.C. Baerg, Description of the larva, pupa and egg of Anopheles (Lophopodomyia) squamifemur Antunes with notes on development (Diptera: Culicidae), J. Med. Ent. 11 (1974) 564-569.

[14] C.J. Stojanovich, J.R. Gorham, H.G. Scott, Clave ilustrada para los mosquitos anofelinos de América Central y Panamá, U.S. Dept. Hlth. Educ. Welf., N.C.D.C., Atlanta, 1966.

[15] J.R. Gorham, C.J. Stojanovich, H.G. Scout, Illustrated key to the anopheline mosquitoes of western South America, Mosq. News 5 (1973) 97-156.

[16] J.S. Simmons, C.H.G. Aitken, The Anopheline mosquitoes of the Northern half of the Western Hemisphere and of the Philippine Islands, Army Med. Bull. 59 (1942) 1-213.

[17] L.M. Deane, O.R. Causey, M.P. Deane, Notas sobre a distribuição e a biologia dos Anofelinos das regiões Nordestina e Amazônica do Brasil, Rev. Serv. Esp. Saúde Pub. 4 (1948) 827965.

[18] W.P. Tadei, B.D. Thatcher, J.M.M. Santos, V.M. Scarpassa, I.B. Rodrigues, M.S. Rafael, Ecologic observations on Anopheline vectors of Malaria in the Brazilian Amazon, Am. J. Trop. Med. Hyg. 59 (1998) 325-335.

[19] M. Vargas, Clave para Anofelinos adultos (Hembras) de Costa Rica (Diptera, Culicidae), Brenesia 6 (1975) 77-80.
[20] H. Floch, E. Abonnec, Présence de Anopheles (Lophopodopyia) squamifemur Antunes 1937 en Guyane Française, Arch. Inst. Pasteur Guyane Terr. Inini. 139 (1946) 1-4.

[21] F.S. Blanton, E.L. Peyton, Notes and distribution records of Anopheles and Chagasia mosquitoes in Panama Based on a three year light trap survey, Mosq. News 16 (1956) 22-26.

[22] G. Calderón, R. Fernández, J. Valle, Especies de la fauna anofelina, su distribución y algunas consideraciones sobre su abundancia e infectividad en el Perú, Rev. Peruana Epidemiol. 8 (1995) $5-23$.

[23] J.E. Hudson, Bloodsucking Diptera (Culicidae, Psychodidae, Ceratopogonidae, Simuliidae, Tabanidae) collected in Suriname, 1978-1982, Acta Leidensia 57 (1988) 1-27.

[24] R. Levi-Castillo, Atlas de los Anofelinos Sudamericanos, Guayaquil, Ecuador, 1949.

[25] J. Lane, Neotropical Culicidae, vol. I. Dixinae, Chaoborinae and Culicinae, tribes Anophelini, Toxorhynchitini and Culicini (Genus Culex only), Univ. São Paolo, São Paolo, 1953.

[26] P. Galindo, S.J. Carpenter, H. Trapido, Notes on forest mosquitoes of Panamá. I. Haemagogus spegazzinii Falco Kumm et al., Haemagogus iridicolor Dyar, Anopheles (Lophopodomyia) squamifemur Antunes, and Anopheles (Anopheles) fausti Vargas, four new records for the country. (Diptera: Culicidae), Proc. Ent. Soc. Wash. 51 (1949) 277-278.

[27] J. Moreno, Y. Rubio-Palis, P. Acevedo, Identificación de criaderos de anofelinos en un área endémica del estado Bolívar, Venezuela, Bol. Malar. Sanea. Amb. 15 (2000) 21-30.

[28] J.E. Pecor, J. Jones, M.J. Burell, R. Fernandez, F. Carbajal, M. O'Guinn, M. Sardalis, D. Watts, M. Zyzak, C. Calampa, T.A Klein, Annotated checklist of the mosquito species encountered during arboviral studies in Iquitos, Peru (Diptera: Culicidae), J. Am. Mosq. Contr. Assoc. 1 (2000) 210-218.

[29] F.S. Blanton, C.M. Keenan, E.L. Peyton, Mosquitoes collected in horse-baited traps in Panama during 1951 to 1953 inclusive as an index to malaria control, Mosq. Mews 15 (1955) 39-42.

[30] J.N. Belkin, R.X. Schick, S.J. Heinemann, Mosquitoes studies (Diptera, Culicidae). V. Mosquitoes originally described from Middle America, Contrib. Amer. Ent. Inst. 1 (1965) 1-95.

[31] M.A.M. Sallum, R.C. Wilkerson, O.P. Forattini, Taxonomic study of species formely identified as Anopheles mediopunctatus and resurrection of An. costai (Diptera: Culicidae), J. Med. Entomol. 36 (1999) 282-300.

[32] R.C. Wilkerson, M.A.M. Sallum, Anopheles (Anopheles) forattinii: a new species in Series Arribálzagia (Diptera: Culicidae), J. Med. Entomol. 36 (1999) 345-354.

[33] J. Moreno, Y. Rubio-Palis, First report of Anopheles (Anopheles) costai and A. (A.) forattinii (Diptera: Culicidae) from Venezuela Entomotrop. 18 (2003) 211-213.

[34] M.G. Rosa-Freitas, Anopheles (Nyssorhynchus) deaneorum: a new species in the Albitarsis complex (Diptera: Culicidae), Mem. Inst. Oswaldo Cruz 84 (1989) 535-543.

[35] W. Gironda, Dinámica bioecologica de la entomofauna de Anopheles (Diptera: Culicidae) durante seis meses en la localidad de Guayaramerín. MSc Thesis, Universidad Mayor de San Andrès, La Paz, Bolivia, 2002.

[36] R.C. Wilkerson, T.V. Caffigan, J. Bento Lima, Identification of species related to Anopheles (Nysshorhynchus) albitarsis by Random Amplified Polymorphic DNA - Polymerase Chain Reaction (Diptera: Culicidae), Mem. Inst. Oswaldo Cruz 90 (1995) 721-732.

[37] M.A. Lehr, C.W. Kilpatrick, R.C. Wilkerson, J.E. Conn, Cryptic species in the Anopheles (Nyssorhynchus) albitarsis (Diptera: 
Culicidae) complex: Incongruence between Random Amplified Polymorphic DNA-Polymerase Chain Reaction Identification and analysis of mitochondrial DNA COI gene sequences, Ann. Entomol. Soc. Am. 98 (2005) 908-917.

[38] C. Li, R.C. Wilkerson, Identification of Anopheles (Nyssorhynchus) albitarsis complex species (Diptera: Culicidae) using rDNA internal transcribed spacer 2-based polymerase chain reaction primers, Mem. Inst. Oswaldo Cruz 100 (2005) 495-500.

[39] M.E. Faran, K.J. Linthicum, A handbook of the Amazonian species of Anopheles (Nyssorhynchus) (Diptera: Culicidae), Mosq. Syst. 13 (1981) 1-81.

[40] K.J. Linthicum, A revision of the Argyritarsis section of the subgenus Nyssorhynchus, of Anopheles, Mosq. Syst. 20 (1988) 99-271.

[41] J.C. Lien, Informes mensuales al Ministerio de Salud y Deportes de Bolivia sobre el desarrollo de actividades en entomología médica. Doc roneo. Available from: Escuela Técnica de Salud Boliviano-Japonés de Cooperación Andina, Laboratorio de Entomología, Avenida Aniceto Arce 440, Cochabamba, Bolivia, 1985.

[42] M.E. Faran, Anopheles (Nysorhynchus) trinkae, a new species in the Albimanus Section (Diptera: Culicidae), Mosq. Syst. 11 (1979) 26-39.

[43] J.C. Lien, Investigaciones entomológicas realizadas durante el periodo de diciembre de 1981 y Julio de 1983, Sal. Pub. Bol. 14 (1984) 29-32.

[44] M.E. Faran, Mosquito Studies (Diptera, Culicidae) 34. A revision of the Albimanus Section of the subgenus Nyssorhynchus of Anopheles, Contrib. Am. Entomol. Inst. 1 (1980) 1-215.

[45] G.N. Fritz, H. Bermudez, J.A. Seawright, Genetic differentiation and diagnostic loci of Anopheles nuneztovari, An. trinkae, and An. rangeli (Diptera: Culicidae), J. Med. Entomol. 3 (1995) 663672.

[46] G.N. Fritz, S. Engman, R. Rodriguez, R.C. Wilkerson, Identification of four vectors of human Plasmodium spp. by multiplex PCR: Anopheles rangeli, An. strodei, An. triannulatus, and An. trinkae (Diptera: Culicidae: Nyssorhynchus), J. Med. Entomol. 41 (2004) 1111-1115.

[47] J. Haye, G. Calderon, R. Falco, V. Zambrano, Newly incriminated anopheline vectors of human malaria parasites in Junin Department, Peru, J. Am. Mosq. Contr. Assoc. 3 (1987) 418422.

[48] R. Paudel, Molecular identification, distribution and ecology of larval malaria mosquitoes in Carrasco/Chapare Valleys, Bolivia, MSc Thesis, Eastern Illinois University, Charleston, Illinois, 2005.

[49] A. Martinez, Anopheles (Kerteszia) laneanus Corrêa y Cerqueira, 1944, nueva especie para la entomofauna boliviana, Mis. Est. Path. Reg. Arg. 75 (1949) 13-17.

[50] A. Martinez, A. Prosen, Nuevos Culicidos para las entomofaunas de Argentina, Bolivia y Paraguay, Mis. Est. Path. Reg. Arg. 8384 (1953) 27-32.

[51] M.R. Borda, Distribución geográfica de Anofelinos en Bolivia, Rev. Salud Pub. Bol. 27 (1965) 19-27.

[52] J.N. Belkin, R.X. Schick, S. Heinemann, Mosquito studies (Diptera, Culicidae) XI. Mosquitoes originally described from Argentina, Bolivia, Chile, Paraguay, Peru, and Uruguay, Contrib. Amer. Ent. Inst. 4 (1968) 9-29.

[53] K.L. Knight, A. Stone, A Catalog of the Mosquitoes of the
World, vol. VI, Thomas Say Foundation, Entomological Society of America, Baltimore, 1977.

[54] E.L. Peyton, D.R. Roberts, F.P. Pinheiro, R. Vargas, F. Valderrama, Mosquito collections from a remote unstudied area of southeastern Bolivia, Mosq. Syst. 15 (1983) 61-89.

[55] C.L. Brelsfoard, G.N. Fritz, R. Rodriguez, DNA-Based methods for identifying malaria mosquitoes: Species-diagnostic Polymerase Chain Reaction assay for the identification of Anopheles vectors of human Plasmodium spp., Available from: http://www. eiu.edu/ bio_data/posters/2005/poster_060.htm, 2005.

[56] R.C. Wilkerson, Anopheles (Anopheles) calderoni n. sp., a malaria vector of the Arribálzagia series from Peru (Diptera: $\mathrm{Cu}$ licidae), Mosq. Syst. 23 (1991) 25-38.

[57] R.C. Wilkerson, Redescription of Anopheles punctimacula and An. malefactor (Diptera: Culicidae), J. Med. Entomol. 27 (1990) 225-247.

[58] M. Coetzee, J.G. Estrada-Franco, C.A. Wunderlich, H. Hunt, Cytogenetic evidence for a species complex within Anopheles pseudopunctipennis Theobald (Diptera: Culicidae), Am. J. Trop. Med. Hyg. 60 (1999) 649-653.

[59] R.E. Harbach, D.R. Roberts, S. Manguin, Variation in the hindtarsal markings of Anopheles darlingi (Diptera: Culicidae) in Belize, Mosq. Syst. 25 (1993) 192-197.

[60] T.F. Silva-do-Nascimento, Estudo taxonômico e notas sobre a biologia de Anopheles triannulatus (Neiva \& Pinto, 1922) de oito localidades, MSc Thesis, Instituto Oswaldo Cruz, Fiocruz, Rio de Janeiro, 1995.

[61] T.F. Silva-do-Nascimento, R.C. Wilkerson, R. Lourenço-deOliveira, R. Monteiro, Diagnose de três espécies cripticas simpatricas de Anopheles (Nyssorhynchus) triannulatus (Neiva \& Pinto, 1922) (Diptera: Culicidae) de Salobra (MS), Brasil central, através de analise aloenzimatica de RAPD-PCR, XIX Congreso Brasileiro de Parasitologia, Rev. Pat. Trop. 34 (Supl. Esp.) (2005).

[62] A.L.A. Galvão, J. Lane, Observações sobre alguns anofelinos de Salobra, Mato Grosso (Diptera, Culicidae), Rev. Biol. Hyg. 11 (1941) 10-18.

[63] R.A.G.B. Consoli, R. Lourenço-de-Oliveira, Principais mosquitos de importância sanitária no Brasil, Fiocruz, Rio de Janeiro, 1994.

[64] T.F. Silva-do-Nascimento, R. Lourenço-de-Oliveira, Anopheles halophylus, a new species of the subgenus Nyssorhynchus (Diptera: Culicidae) from Brazil, Mem. Inst. Oswaldo Cruz 97 (2002) 801-811.

[65] R. Lourenço-de-Oliveira, L.M. Deane, What is Anopheles allopha (Lutz \& Peryassú, 1921) (Diptera: Culicidae), Mem. Inst. Oswaldo Cruz 79 (1984) 509-510.

[66] M. Atue, Composición y abundancia de la comunidad larvaria del genero Anopheles (Diptera: Culicidae) en dos localidades del rió Espíritu Santo, Provincia Chapare, Departamento de Cochabamba, MSc Thesis, Universidad Mayor de San Simón, Cochabamba, Bolivia, 2003.

[67] L.V. Senice, MAM Sallum, Systematics of Anopheles lanei Galvão and Amaral, a species of the subgenus Nyssorhynchus Blanchard (Diptera: Culicidae), Mem. Inst. Oswaldo Cruz 102 (2007) 959-967.

[68] P. Ibisch, G. Mérida, Biodiversidad: La riqueza de Bolivia, Ministerio de Desarrollo Sostenible. Editorial FAN, Santa Cruz de la Sierra, Bolivia, 2003. 